\title{
Acaricide activity of Piper macedoi Yunck essential oil against Rhipicephalus
}

\author{
sanguineus
}

Atividade acaricida do óleo essencial de Piper macedoi Yunck contra Rhipicephalus sanguineus

Actividad acaricida del aceite esencial de Piper macedoi Yunck contra Rhipicephalus sanguineus

Received: 12/10/2021 | Reviewed: 12/17/2021 | Accept: 12/24/2021| Published: 01/04/2022

Veridiane Marques Bezerra

ORCID: https://orcid.org/0000-0003-4064-2502 Universidade Federal do Sul da Bahia, Brazil

E-mail: veridiane.marques@gmail.com

Emília Gabriela Santos Ferreira

ORCID: https://orcid.org/0000-0002-6282-4094

Universidade Federal do Sul da Bahia, Brazil

E-mail: emiliagabriela.sf@hotmail.com

Gildásio Warllen dos Santos

ORCID: https://orcid.org/0000-0003-2141-8601

Universidade Federal do Sul da Bahia, Brazil

E-mail: gildasioqueiroz@hotmail.com

Gisele Lopes de Oliveira

ORCID: https://orcid.org/0000-0001-8036-299X

Universidade Federal do Sul da Bahia, Brazil

E-mail: gisele.lopes@ufsb.edu.br

Davyson de Lima Moreira

ORCID: https://orcid.org/0000-0002-3060-0395

Fundação Oswaldo Cruz, Brazil

E-mail: davysonmoreira@hotmail.com

Thallyta Maria Vieira

ORCID: https://orcid.org/0000-0002-1483-6234

Universidade Estadual de Montes Claros, Brazil

E-mail: thallytabio@gmail.com

Eduardo Robson Duarte

ORCID: https://orcid.org/0000-0002-2205-9412

Universidade Federal de Minas Gerais, Brazil

E-mail: duartevet@hotmail.com

Rodrigo Guimarães de Deus

ORCID: https://orcid.org/0000-0003-4220-0935

Universidade Federal do Sul da Bahia, Brazil

E-mail: rguimaraes3@hotmail.com

Matheus Ramalho de Lima

ORCID: https://orcid.org/0000-0002-9897-6209

Universidade Federal do Sul da Bahia, Brazil

E-mail: mrlmatheus@gmail.com

Márcia Nunes Bandeira Roner

ORCID: https://orcid.org/0000-0002-5230-4036

Universidade Federal do Sul da Bahia, Brazil

E-mail:marcia@ufsb.edu.br

\begin{abstract}
This study evaluated the acaricide efficacy of Piper macedoi essential oil on larvae of ticks of the species Rhipicephalus sanguineus. The essential oil was extracted by hydrodistillation in a Clevenger-type apparatus. The test consisted of six treatments: from the group I to IV, samples corresponded to different concentrations of essential oil $\left(500 \mu \mathrm{g} . \mathrm{mL}^{-1} ; 250 \mu \mathrm{g} \cdot \mathrm{mL}^{-1} ; 100 \mu \mathrm{g} \cdot \mathrm{mL}^{-1}\right.$ and $\left.50 \mu \mathrm{g} . \mathrm{mL}^{-1}\right)$ diluted in Tween 80 at $2 \%$. Groups V and VI corresponded to the negative controls (with distilled water and Tween 80 to 2\%) and the positive control (with acaricide Amitraz at $12.5 \%)$, respectively. The essential oil was rich in apiole $(39.81 \%)$ and dillapiole $(26.47 \%)$. The essential oil of $P$. macedoi presented an activity against the larvae of $R$. sanguineus, with a better efficiency observed for concentrating $500 \mu \mathrm{g} . \mathrm{mL}^{-1}$, mortality of $80.67 \%$, indicating a dose-dependent response.
\end{abstract}

Keywords: Piperaceae; Tick; Larvicidal activity; Apiole; Dillapiole. 


\begin{abstract}
Resumo
O objetivo deste estudo foi avaliar a eficácia acaricida do óleo essencial de Piper macedoi em larvas de carrapatos da espécie Rhipicephalus sanguineus. O óleo essencial foi extraído por hidrodestilação em aparelho do tipo Clevenger. O teste consistiu em seis tratamentos: do grupo I ao IV, as amostras corresponderam às diferentes concentrações de óleo essential $\left(500 \mu \mathrm{g} \cdot \mathrm{mL}^{-1} ; 250 \mu \mathrm{g} \cdot \mathrm{mL}^{-1} ; 100 \mu \mathrm{g} \cdot \mathrm{mL}^{-1}\right.$ e $\left.50 \mu \mathrm{g} . \mathrm{mL}^{-1}\right)$ diluído em Tween 80 à $2 \%$. Os grupos V e VI corresponderam aos controles (com água destilada e Tween 80 a 2\%) e o controle positivo (com o acaricida Amitraz a $12,5 \%)$, respectivamente. O óleo essencial mostrou-se rico em apiol $(39,81 \%)$ e dilapiol $(26,47 \%)$. O óleo essencial de $P$. macedoi apresentou uma atividade contra as larvas de $R$. sanguineus, com uma melhor eficiência observada para a concentração de $500 \mu \mathrm{g} \cdot \mathrm{mL}^{-1}$, mortalidade de 80,67\%, indicando resposta dependente da dose.
\end{abstract}

Palavras-chave: Piperaceae; Carrapatos; Atividade larvicida; Apiol; Dilapiol.

\title{
Resumen
}

El propósito de este estudio fue evaluar la eficacia acaricida del aceite esencial de Piper macedoi en larvas de garrapatas de la especie Rhipicephalus sanguineus. El aceite esencial se extrajo por hidrodestilación con un aparato tipo Clevenger. El ensayo consta de seis tratamientos: del grupo I al IV, las muestras corresponden a diferentes concentraciones del aceite esencial $\left(500 \mu \mathrm{g} \cdot \mathrm{mL}^{-1} ; 250 \mu \mathrm{g} \cdot \mathrm{mL}^{-1} ; 100 \mu \mathrm{g} \cdot \mathrm{mL}^{-1}\right.$ e $\left.50 \mu \mathrm{g} \cdot \mathrm{mL}^{-1}\right)$ diluido en Tween 80 al $2 \%$. Los grupos V y VI corresponden a los controles (con agua destilada y Tween 80 a $2 \%$ ) y el control positivo (con el acaricida Amitraz a 12,5\%), respectivamente. El aceite esencial resultó ser rico en apiol $(39,81 \%)$ y dilapiol (26,47\%). El aceite esencial de P. macedoi presentó una actividad contra larvas de $R$. sanguineus, con una mejor eficiencia observada para la concentración de $500 \mu \mathrm{g} \cdot \mathrm{mL}^{-1}, 80,67 \%$ de mortalidad, indicando una respuesta dependiendo de la dosis.

Palabras clave: Piperaceae; Garrapatas; Actividad larvicida; Apiol; Dilapiol.

\section{Introduction}

Ticks have called the interest of public health and the scientific community due to their impact on the transmission of diseases. These parasites are part of the group of important vectors of infectious agents for animals and the second in importance for humans, only behind the group of mosquitoes (Araújo et al., 2015a). Species such as Ambyoma cajennense and Rhipicephalus sanguineus are important vectors of Rickettsia rickettsii, the etiological agent of spotted fever in Brazil and other Latin American countries (Moraes-Filho, 2009; Vélez et al., 2012).

In Brazil, the two most prevalent species are Boophilus microplus and Rhipicephalus sanguineus, which mainly affect cattle and dogs, respectively. R. sanguineus transmits dog Babesia canis, Babesia gibsonii, and Ehrlichia canis, the unclassified agents of canine hemoplasmosis (haemobartonellosis); Hepatozoon canis and Bartonella vinsonii (Olivo et al., 2008; Araújo et al., 2015b).

The canine babesiosis, zoonosis transmitted by tick bites whose agents are intraerythrocytic hemoprotozoa of the genus Babesia, can also be transmitted to humans (Dantas-Torres \& Figueredo, 2006; Araújo et al., 2015b). Another tickrelated zoonosis is the Lyme-like infection syndrome (Baggio-Yoshinari disease) caused by bacteria of the genus Borrelia, which, although uncommon in Brazil, has confirmed cases in some regions, such as in the States of Tocantins and Espírito Santo (Martins et al., 2009; Mantovani et al., 2007; Yoshinari et al., 2010). The occurrence of Rhipicephalus sanguineus in humans is common, especially among people who work in veterinary clinics and kennels (Louly et al., 2006) because dogs from urban or rural areas, raised in kennels, with limited space, are the natural hosts of R. sanguineus. An engorged female of this species can make oviposition within human dwellings, leading to the development of adults (Massard \& Fonseca, 2004) and, despite the great preference for the dog, R. sanguineus can also sting people (Mentz et al., 2016).

Tick control is usually performed with the application of organo-synthetic acaricides indiscriminately, which often results in poisoning of animals and applicators; in acaricidal residues in animal products; development of resistance of ticks to chemical acaricides; as well as environmental pollution (Campos et al., 2012).

An alternative that is increasing in appeal, late, is the search for bioacaricidals of natural source, derived from substances of special plant metabolism that produces a great diversity of compounds with acaricidal action. These resources can be explored using essential oils or compounds as a model for the synthesis of synthetic pesticides (Nwanade et al., 2020). 
The use of natural and phyto-therapeutic products show lower toxicity to mammals, slower development of parasitic resistance, and are biodegradable, thus providing low environmental impact and a reduced number of residues in products of animal origin (Chagas, 2004; Veríssimo \& Katiki, 2015).

Piperaceae is a plant family possessing a rich diversity in essential oils, that is composed by monoterpenes, sesquiterpenes and arylpropanoids responsible for interesting biological properties (Santos et al., 2001; Oliveira et al., 2013; Salehi et al., 2019). Piper macedoi Yunck is a native species of the Brazilian Atlantic Forest, without reports in the literature on pharmacological studies or biological tests. In this context, this evaluate the acaricide efficacy of $P$. macedoi essential oil on $R$. sanguineus larvae. This study is a pioneer for biological assays of $P$. macedoi essential oil.

\section{Methodology}

\subsection{Collection of plant material and chemical analysis of the essential oil}

Samples of Piper macedoi Yunch were collected in a fragment of the Atlantic Forest located in the Palmeiras Farm,

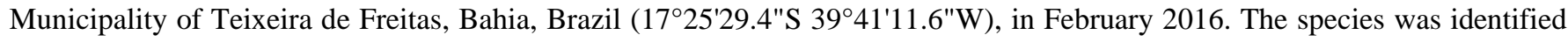
by Dr. Elsie F. Guimarães of the Botanical backyard Research Institute of Rio de Janeiro and deposited in the Herbarium with voucher identification RB 73273. The authorization for collecting species was granted by the Biodiversity Authorization and Information System (SISBIO) (number 31544).

For extracting the essential oil of $P$. macedoi, used in the acaricide assay, fresh leaves $(100 \mathrm{~g})$ were submitted to hydrodistillation in a Clevenger-type apparatus for $2 \mathrm{~h}$, in the Interdisciplinary Laboratory of the Federal University of Southern Bahia-UFSB, with a yield of $0.4 \%$. Chemical analysis of the essential oil (solution in dichloromethane at $1 \mathrm{mg} \cdot \mathrm{mL}^{-1}$ ) was performed by gas chromatography coupled to the flame ionization detector (GC-FID) and by GC coupled to mass spectrometry (GC-MS) at the Analytical Platform of Farmaguinhos, FIOCRUZ, Rio de Janeiro. The CG-FID analysis conditions were HP-5MS column (30-m x $0.32 \mathrm{~mm}$ i.d. x $0.25 \mu \mathrm{m}$ film thickness), temperature programming from $60{ }^{\circ} \mathrm{C}$ to $240{ }^{\circ} \mathrm{C}$, with an increment of $3{ }^{\circ} \mathrm{C} \cdot \mathrm{min}^{-1}$, using hydrogen and synthetic air as carrier gases, with a flow rate at $1.0 \mathrm{~mL} \cdot \mathrm{min}^{-1}$. The retention indexes (IR) were determined from the retention time of a homologous series of hydrocarbons $\left(\mathrm{C}_{8}-\mathrm{C}_{28}\right.$, SigmaAldrich Brazil), obtained by GC-FID, under the same conditions of analysis of the essential oils. The column and temperature conditions by GC-MS analysis were the same for GC-FID. Helium (> 99.99\%) was used as the carrier gas with a flow rate at $1.0 \mathrm{~mL} \cdot \mathrm{min}^{-1}$.

The substances present in the essential oil were identified by comparing their mass spectra with database registration (WILEY7n) and by comparing the Retention Indexes (RI) calculated with those in the literature (Adams, 2017). The quantification of substances in the essential oil was estimated by the chromatogram area obtained using GC-FID.

\subsection{Piper macedoi essential oil acaricide activity}

For the acaricide assay, engorged females of Rhipicephalus sanguineus were collected from dogs in veterinary clinics, NGOs and free-living animals from different neighborhoods of the municipality of Teixeira de Freitas.

The females were sanitized with distilled water and dried with sterilized filter paper, then placed in a Petri dish and incubated in an incubator at $25{ }^{\circ} \mathrm{C}$ and relative humidity of $85 \%$ for oviposition (Labruna et al., 2002). After 14 days, the eggs were collected and packed in a plastic syringe adapted to observe the beginning of hatching and, after that, another 14 days were waited before the acaricide test with the larvae.

The larvae were transferred to a Petri dish containing distilled water and with the aid of a brush. A total of 100 larvae were placed between two pieces of filter paper $(2 \times 2 \mathrm{~cm})$ impregnated with the treatment solutions $(0.4 \mathrm{~mL}$ for each repetition). This "sandwich" was placed in a filter paper envelope $(6 \times 6 \mathrm{~cm})$, sealed by a double tape and stapled (Lambert et 
al., 2021). The envelopes were placed in an air-conditioned incubator $\left( \pm 27^{\circ} \mathrm{C}\right.$ and $\left.\mathrm{RH}>80 \%\right)$ and the recording of live and dead larvae was performed after $24 \mathrm{~h}$.

The test consisted of six treatments, from the group I to IV corresponding to the different concentration of $P$. macedoi essential oil $\left(500 ; 250 ; 100\right.$ and $\left.50 \mu \mathrm{g} \cdot \mathrm{mL}^{-1}\right)$ diluted in Tween 80 at 2\%. Groups V and VI corresponded to the negative control (with distilled water and Tween 80 at 2\%) and the positive control (Amitraz at 12.5\%), respectively. The experiment was conducted in triplicate.

To calculate mortality, the following formula was used: Mortality $(\%)=$ Dead larvae x 100/Total larvae. The mean mortality was defined as the mean mortality $(\%)=$ repetition mortality $1+$ repetition mortality $2+$ repetition mortality 3 .

The results were analyzed with Tukey test at $1 \%$ probability $(p<0.001)$, using the Statistical Package Sisvar (2015). To determine the lethal concentrations (LC) capable of causing 50\% ( $\mathrm{LC}_{50}$ ) and 90\% (LC 90 ) of larvae mortality, the Probit regression analysis was used, within a 95\% confidence interval using Statgraphics centurion XVI, version 16.2.04 (2015).

\section{Results and Discussion}

\subsection{Chemical composition of Piper macedoi essential oil}

It was possible to identify 44 compounds in the chemical analysis of the essential oil of Piper macedoi leaves, distributed mainly among monoterpenes (12.78\%), sesquiterpenes (17.20\%) and arylpropanoids (68.43\%). The major substances found were arylpropanoids apiole (39.81\%) and dillapiole (26.47\%), followed by the sesquiterpene bicyclogermacrene $(4.88 \%)$ and monoterpenes $(E)$ - $\beta$-ocimene $(4.55 \%)$ and $\beta$-pinene $(3.21 \%)$ (Table 1$)$.

Table 1: Chemical characterization of the Piper macedoi essential oil from Atlantic Forest of the South of Bahia, Brazil.

\begin{tabular}{|c|c|c|c|}
\hline Substances & RI & RILit & Relative Percentage \% \\
\hline Tricyclene & 931 & 926 & 1.02 \\
\hline$\beta$-Pinene & 977 & 979 & 3.21 \\
\hline Myrcene & 988 & 990 & 0.15 \\
\hline$\alpha$-Phellandrene & 999 & 1002 & 0.03 \\
\hline Limonene & 1028 & 1029 & 0.20 \\
\hline (Z)- $\beta$-Ocimene & 1033 & 1037 & 2.02 \\
\hline (E)- $\beta$-Ocimene & 1044 & 1050 & 4.55 \\
\hline Linalool & 1100 & 1096 & 0.42 \\
\hline Allocimene & 1137 & 1132 & 0.23 \\
\hline Safrole & 1288 & 1297 & 0.16 \\
\hline 2-Undecanone & 1293 & 1294 & 0.13 \\
\hline Neo Verbenol Iso-Acetate & 1328 & 1330 & 0.98 \\
\hline$\beta$-Elemene & 1386 & 1390 & 0.68 \\
\hline (E)-Caryophyllene & 1416 & 1419 & 1.38 \\
\hline$\alpha$-Humulene & 1456 & 1454 & 0.27 \\
\hline Germacrene D & 1485 & 1481 & 0.52 \\
\hline Valencene & 1497 & 1496 & 0.12 \\
\hline Bicyclogermacrene & 1497 & 1500 & 4.88 \\
\hline$\alpha$-Muurolene & 1500 & 1500 & 0.24 \\
\hline$n$-Pentadecane & 1505 & 1500 & 0.10 \\
\hline Cubebol & 1514 & 1515 & 1.23 \\
\hline Nootkatone & 1517 & 1518 & 0.95 \\
\hline
\end{tabular}




\begin{tabular}{lccc} 
Mirysticin & 1520 & 1518 & 1.56 \\
trans-Cadina-1,4-diene & 1528 & 1534 & 0.10 \\
Elemicin & 1544 & 1557 & 0.43 \\
(E)-Nerolidol & 1555 & 1563 & 1.56 \\
Germacrene D-4-ol & 1564 & 1575 & 1.24 \\
$\alpha$-Cedrene epoxide & 1567 & 1575 & 0.17 \\
Spathulenol & 1570 & 1578 & 0.26 \\
Presilphiperfolan-8-ol & 1573 & 1583 & 0.16 \\
Thujopsan-2- $\beta$-ol & 1575 & 1589 & 0.26 \\
Guaiol & 1578 & 1600 & 0.13 \\
$\beta$-Oplopenone & 1586 & 1607 & 0.17 \\
Humulene Epoxide II & 1590 & 1608 & 0,20 \\
Dilapiolle & 1603 & 1620 & $\mathbf{2 6 . 4 7}$ \\
10-epi- $\gamma$-Eudesmol & 1612 & 1623 & 0.34 \\
Eremoligenol & 1622 & 16,31 & 0.11 \\
Epi- $\alpha$-Cadinol & 1639 & 1640 & 0.30 \\
Epi- $\alpha$-Muurolol & 1642 & 1642 & 0.48 \\
Agarospirol & 1647 & 1648 & 0.19 \\
$\alpha$-Cadinol & 1662 & 1654 & 0.77 \\
cis-Calamenen-10-ol & 1693 & 1661 & 0.15 \\
Apiole & 1703 & 1678 & $\mathbf{3 9 . 8 1}$ \\
Shyobunol & 1712 & 1689 & 0.35 \\
\hline Monoterpenes & & & $\mathbf{1 2 . 7 8}$ \\
Sesquiterpenes & & $\mathbf{1 7 . 2 0}$ \\
Arylpropanoids & & & $\mathbf{9 8 . 4 1}$ \\
\hline Total \% & & & \\
\hline & & & \\
\hline & & & \\
\hline
\end{tabular}

Fonte: Autores (2021).

The chemical study of P. macedoi collected in an Atlantic Forest area is a pioneer work, and there are no reports in the literature of biological assays performed neither with extracts nor with essential oils of this species. However, chemical analyses of the essential oil of $P$. macedoi leaves were performed using specimens collected in a bush savanna (Cerrado) area in the State of Minas Gerais (Oliveira et al., 2016). This study showed that monoterpenes were identified as the major compounds, both for the wild plant sample $(46.2 \%)$ as for a cultivated sample $(46.7 \%)$, being $(E)$ - $\beta$-ocimene the substance present in the highest concentration (wild plant $28.5 \%$; cultivated plant $24.9 \%$ ). The class of arylpropanoids also appeared in great percentual content (wild plant $25.3 \%$; cultivated plant $23.5 \%$ ), being partisan the majority compound (wild plant $14.1 \%$; cultivated plant $17.8 \%$ ). Dilapiolle was identified in this sample at low concentration (wild plant $1.1 \%$; cultivated plant $1.8 \%$ ) and apiole was not registered in the essential oil of P. macedoi from Cerrado site. The sesquiterpene fraction (wild plant 20.9\%; cultivated plant 22.6\%) was also found in reasonable content, with germacrene $\mathrm{D}$ as the major compound for this group (wild plant 3.7\% and cultivated plant 3.2\%) (Oliveira et al., 2016). The differences between the major compounds found in $P$. macedoi essential oil from the Atlantic Forest probably occur due to environmental and climatic differences. 


\subsection{Piper macedoi Yunch essential oil acaricidal activity}

The essential oil from leaves of $P$. macedoi was shown to be effective, presenting an acaricidal activity against the larvae of $R$. sanguineus. After $24 \mathrm{~h}$ of larvae exposure to different essential oil concentrations, a mortality of $80.67 \%$ was observed at a concentration of $500 \mu \mathrm{g} \cdot \mathrm{mL}^{-1}$, presenting a result similar to the one observed for amitraz acaricide, which produced $82.33 \%$ of mortality. Concentrations of 250,100 , and $50 \mu \mathrm{g} \cdot \mathrm{mL}^{-1}$ showed mortality rates of $55.00 \% ; 52.67 \%$ and $58.00 \%$, respectively (Table 2 ).

Table 2 - Percentage of mortality of $R$. sanguineus larvae exposed to different concentrations of P. macedoi essential oil.

\begin{tabular}{cc}
\hline Treatments $\left(\boldsymbol{\mu g} \cdot \mathbf{m L}^{-1}\right)$ & Mortality of larvae* $^{*}$ \\
\hline $\mathbf{5 0 0}$ & $80.67^{\mathrm{ab}}$ \\
$\mathbf{2 5 0}$ & $55.00^{\mathrm{c}}$ \\
$\mathbf{1 0 0}$ & $52.67^{\mathrm{c}}$ \\
$\mathbf{5 0}$ & $58.00^{\mathrm{bc}}$ \\
Amitraz 12.5\% & $82.33^{\mathrm{a}}$ \\
Distilled water and Tween 80, 2\% & $0.00^{\mathrm{d}}$ \\
\hline
\end{tabular}

*Averages followed by the same letters do not differ from each other by the Tukey test at $1 \%$ probability $(\mathrm{p}<0.001)$. Fonte: Autores (2021).

There was an increase in the efficacy of the mortality rate of $R$. sanguineus larvae proportional to the increase in the concentration of essential oil, indicating a dose-dependent response (Figure 1). The $\mathrm{LC}_{50}$ and $\mathrm{LC} 90$ for the essential oil of $P$. macedoi were calculated at $221.946 \mu \mathrm{g} \cdot \mathrm{mL}^{-1}$ and $557.084 \mu \mathrm{g} \cdot \mathrm{mL}^{-1}$, respectively (Figure 1). Thus, the data suggest a higher dose of essential oil to present a mortality rate of more than $90 \%$ and to present results higher than Amitraz.

Figure 1 - Variation in mortality of $R$. sanguineus larvae exposed to different concentrations of $P$. macedoi essential oil. Probit regression test with $95 \%$ confidence interval.

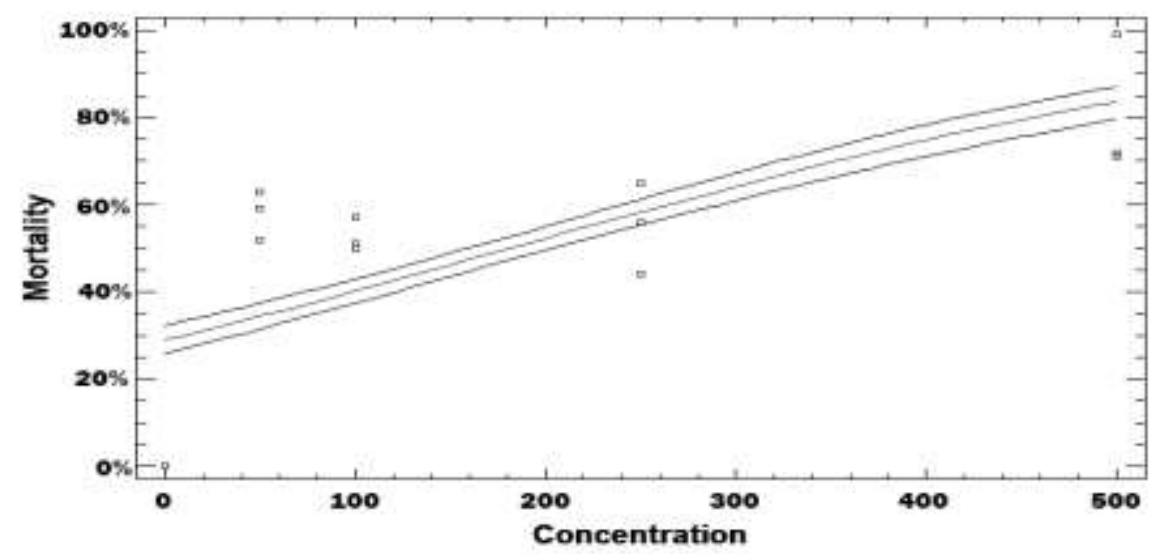

Fonte: Autores (2021).

The drug of choice for the environmental treatment, where $95 \%$ of the tick population can be found, has long been based on pyrethroids because this class of acaricide has greater residual power (Labruna \& Machado, 2006). However, recently, due to the increase in resistance to pyrethroids, these were replaced by formamidines (Amitraz), to which, in the same way, some tick populations are creating resistance (Farias et al., 2008; Santos et al., 2009). Thus, the search for new products, 
especially of natural sources, is an alternative that should be considered. The results presented here, with similar activities between the essential oil of $P$. macedoi $\left(500 \mu \mathrm{g} . \mathrm{mL}^{-1}\right)$ and the drug Amitraz suggests the possibility of an alternative product to be used in environments and facilities where tick larvae are usually found, and even in the dog, after appropriate toxicological tests.

As observed in this study, the chemical composition of many essential oils, showing monoterpenes and sesquiterpenes, is responsible for repellency and biocide activities against the tick $R$. (B.) microplus (Facey et al., 2005; Gazim et al., 2011). These components, with arylpropanoids, especially represented by apiole, dillapiole, myristicin, safrole and sarisan, are found in species of the family Piperaceae, also show interesting biological properties (Santos et al., 2001, Salehi et al., 2019). Indeed, species of Piperaceae rich in arylpropanoids, such as Piper aduncum L., are also bioactive, demonstrating the activity against Schistosoma sp. As well as insecticide, larvicide and fungicide activities (Almeida et al., 2009). According to the literature, the major compounds of the essential oil of $P$. aduncum from Amazon region are the arylpropanoid dillapiole, responsible for most of the biological activities of the species (Almeida et al., 2009). Another study also conducted with $P$. aduncum showed excellent activity against $R$. (B.) microplus. The essential oil recovered from the hexane extract of this plant presented, in its chemical constitution, the arylpropanoid dillapiole as the main substance (94.84\%) and an activity capable of causing the mortality of $100 \%$ of $R$. microplus larvae at low concentrations $\left(0.1 \mathrm{mg} \cdot \mathrm{mL}^{-1} ; 0.5 \mathrm{mg} \cdot \mathrm{mL}^{-1} ; 1 \mathrm{mg} \cdot \mathrm{ml}^{-1}\right)$ (Silva et al., 2009).

Comparing the data presented in the literature and considering that in this study the essential oil of $P$. macedoi showed $66.28 \%$ of the chemical constitution of its essential oil represented by arylpropanoids (apiole $-39.81 \%$ and dillapiole $26.47 \%$ ), it is possible to associate the larvicidal activity with the presence of these compounds. A synergistic effect between then may be considered. In fact, the synergy between compounds from plant extracts and essential oils is one of the main advantages in the use of natural products in relation to synthetic drugs, as they can have more than one active ingredient acting synergistically, potentiating the biological activity in question, also hindering the formation of resistance of ticks, unlike synthetic products (Mgbojikwe \& Okoye, 2004).

\section{Conclusion}

It was possible to conclude that the essential oil from fresh leaves of P. macedoi showed an activity against the larvae of $R$. sanguineus, with a better efficiency observed for concentrating $500 \mu \mathrm{g} \cdot \mathrm{mL}^{-1}$, also indicating a dose-dependent response. Also, it is possible to suggest that the larvicidal activity against $R$. sanguineus presented here may be associated with apiole and dillapiole, not ruling out synergy between all compounds.

\section{Acknowledgments}

Authors thank to UFSB to financial assistance and Dr.Victor Gomes Curty and Mr. Nelson Nunes Curty, owners of the Palmeiras farm, for their permission and help in collecting the plant material.

\section{References}

Adams, R.P. (2017). Identification of essencial oil components by gas chromatography/ mass spctrometry. Allured Publishing Corporation: Carol Stream, Illinois, 809p.

Almeida, R.R.P., Souto, R.N.P., Bastos, C.N., Silva, M.H.L., Maia, J.G.S. (2009). Chemical variation in Piper aduncum and biological properties of its dillapiole-rich essential oil. Chemistry \& Biodiversity, 6, 1427-1434. https://doi.org/10.1002/cbdv.200800212.

Araújo, R.P., Navarro M.B.M.A., Cardoso, T.A.O. (2015a). Spotted fever in Brazil: mortality study for epidemiological surveillance. Caderno de Saúde Coletiva, 23, 354-361. https://doi.org/10.1590/1414-462X201500040094. 
Araújo, A.C., Silveira, J.A.G., Azevedo, S.S., Nieri-Bastos, F.A., Ribeiro, M.F.B., Labruna, M.B., Horta, M.C. (2015b). Babesia canis vogeli infection in dogs and ticks in the semiarid region of Pernambuco, Brazil. Pesquisa Veterinária Brasileira, 35 (5), 456-461. https://doi.org/10.1590/S0100-736X2015000500012.

Campos, R.N.S., Bacci, L., Araújo, A.P.A., Blank, A.F., Arrigoni-Blank, M.F., Santos, G.R.A., Roner, M.N.B. (2012). Óleos Essenciais de Plantas Medicinais e Aromáticas no Controle do Carrapato Rhipicephalus Microplus. Archivos de Zootecnia, 61, 67-78. https://doi.org/10.21071/az.v61i237.2959.

Chagas, A.C.S. (2004). Controle de parasitas utilizando extratos vegetais. Revista Brasileira de Parasitologia Veterinária, 13, $156-160$.

Dantas-Torres, F., Figueredo, L.A. (2006). Canine babesiosis: a Brazilian perspective. Veterinary Parasitology, 141, 197-203. https://doi.org/10.1016/j.vetpar.2006.07.030

Facey, P.C., Porter, R.B.R., Reese, P.B., Williams, L.A.D. (2005). Biological activity and chemical composition of the essential oil from Jamaican Hyptis verticillata Jacq. Journal of Agricultural and Food Chemistry, 53, 4774-4777. https://doi.org/10.1021/jf050008y.

Farias, N.A., Ruas, J.L., Santos, T.R.B. (2008). Análise da eficácia de acaricidas sobre o carrapato Boophilus microplus, durante a última década, na região sul do Rio Grande do Sul. Ciência Rural, 38 (6), 1700-1704. http://dx.doi.org/10.1590/S0103-84782008000600032.

Gazim, Z.C., Demarchi, I.G., Lonardoni, M.V.C., Amorim, A.C.L., Hovell, A.M.C., Rezende, C.M., Ferreira, G.A., Lima, E.L., Cosmo. F.A., Cortez, D.A.G. (2011). Acaricidal activity of the essential oil from Tetradenia riparia (Lamiaceae) on the cattle tick Rhipicephalus (Boophilus) microplus (Acari; Ixodidae). Experimental Parasitology, 129, 175-178. https://doi.org/10.1016/j.exppara.2011.06.011

Labruna, M.B., Paula, C.D., Lima, T.F., Sana, D.A. (2002). Ticks (Acari: Ixodidae) on wild animals from the Porto Primavera Hydroelectric power station area, Brazil. Memoria Instuicional Oswaldo Cruz, 97, 1133-1136. https://doi.org/10.1590/S0074-02762002000800012

Labruna, M.B., Machado, R.Z. (2006). Agentes transmitidos por carrapatos na região neotropical. In: Barros-Batesti, D.M., Arzua, M., Bechara, G.H. Carrapatos de importância médico-veterinária da região neotropical, um guia ilustrado para identificação de espécies. São Paulo: Instituto Butantan, 115138.

Lambert, M.M., Chaves, D.S.A., Avelar, B.R., Campos, D.R., Borges, D.A.B., Moreira, L.O., Pereira, G.A., Cid, Y.P., Scott, F.B., Coumendouros, K. (2021). In vitro evaluation of the acaricidal activity of Syzygium aromaticum (L.) essential oil and eugenol against non-fed larvae of Rhipicephalus sanguineus Brazilian Journal of Veterinary Medicine, 43, e002620. https://doi.org/10.29374/2527-2179.bjvm002620

Louly, C.C.B., Fonseca, I.N., Oliveira, V.F., Borges, L.M.F. (2006). Ocorrência de Rhipicephalus sanguineus em Trabalhadores de Clinicas Veterinárias e Canis, no município de Goiânia, GO. Ciência Animal Brasileira, 7, 103-106.

Martins, T.F., Spolidorio, M.G., Batista, T.C.A., Oliveira, I.A.S., Natalino, H., Yoshinari, N.H., Labruna, M.B. (2009). Ocorrência de carrapatos (Acari: Ixodidae) no município de Goiatins, Tocantins. Revista Brasileira de Parasitologia Veterinária, 18, 50-52. https://doi.org/10.4322/rbpv.01802011.

Mantovani E.; Costa, I.P.; Gauditano, G.; Bonoldi, V.L.N.; Higuchi, M.L.; Yoshinari, N.H. (2007). Description of Lyme disease-like syndrome in Brazil. Is it a new tick borne disease or Lyme disease variation? Brazilian Journal of Medical and Biological Research, 40, 443-456. https://doi.org/10.1590/S0100879 X2006005000082.

Massard, C.L., Fonseca, A.H. (2004). Carrapatos e doenças transmitidas comuns ao homem e aos animais. Hora Veterinária, $135,15-23$.

Mentz, M. B., Trombka, M., Silva, G. L., \& Silva, C. E. (2016). Rhipicephalus sanguineus (ACARI: IXODIDAE) biting a human being in Porto Alegre city, Rio Grande do Sul, Brazil. Revista do Instituto de Medicina Tropical de Sao Paulo, 58, 35. https://doi.org/10.1590/S1678-9946201658035

Mgbojikwe, L.O., Okoye, S.C. (2001). Acaricidal Efficacy of the Aqueous Stem Bark Extract of Adenium obesum on the Various Life Stages of Cattle Ticks. Nigerian Journal of Experimental and Applied Biology, 2, 39-43. https://doi.org/10.4102/ojvr.v86i1.1665

Moraes-Filho, J. Pinter A, Pacheco RC, Gutmann TB, Barbosa SO, Gonzáles MA, Muraro M.A, Cecílio SR, Labruna MB. (2009). New epidemiological data on Brazilian spotted fever in an endemic area of the state of São Paulo, Brazil. Vector Borne Zoonotic Diseases, 9, 73-78. https://doi.org/10.1089/vbz.2007.0227

Nwanade, C.F., Wang, M., Wang, T., Yu, Z., Liu, J. (2020). Botanical acaricides and repellents in tick control: current status and future directions. Experimental and Applied Acarology, 81, 1-35. https://doi.org/10.1007/s10493-020-00489-z.

Oliveira GL, Moreira DL, Mendes ADR, Guimarães EF, Figueiredo LS, Kaplan, M.A.C.; Martins, E.R. (2013). Growth study and essential oil analysis of Piper aduncum from two sites of Cerrado biome of Minas Gerais State, Brazil. Revista Brasileira de Farmacognosia, 23, 743-753. https://doi.org/10.1590/S0102-695X2013000500005.

Oliveira, G.L., Matos, C.C., Santos, R.R., Maia, J.T.S., Martins, E.R., Figueiredo, L.S., Moreira, D.L., Kaplan, M.A.C. (2016). Rooting of cuttings and analysis of essential oils from wild and cultivated Piper macedoi Yunck. Revista Brasileira de Plantas Medicinais, 18, 782-790.

Olivo, C.J., Carvalho, N.C., Silva, J.H., Vogel, F.F. Massariol P, Meinerz G, Agnolin C, Morel AF, Viau LV. (2008). Óleo de citronela no controle do carrapato de bovinos. Ciência Rural, 38, 406-410. http://dx.doi.org/10.1590/S0103-84782008000200018.

Salehi, B., Zakaria, Z.A., Gyawali, R., Ibrahim, S.A., Rajkovic, J., Shinwari, Z.K., Khan, T., Sharifi-Rad, J., Ozleyen, A., Turkdonmez, E., Valussi, M., Tumer, T.B., Fidalgo, L.M., Martorell, M., Setzer, W.N. (2019). Piper Species: A Comprehensive Review on Their Phytochemistry, Biological Activities and Applications. Molecules, 24, 1364. https://doi.org/10.3390/molecules24071364

Santos, P.R.D., Moreira, D.L., Guimarães, E.F. Kaplan, M.A.C. (2001). Essential oil analysis of 10 Piperaceae species from the Brazilian Atlantic forest. Phytochemistry, 58, 547-551. https://doi.org/10.1016/S0031-9422(01)00290-4. 
Research, Society and Development, v. 11, n. 1, e18911124610, 2022

(CC BY 4.0) | ISSN 2525-3409 | DOI: http://dx.doi.org/10.33448/rsd-v11i1.24610

Santos, T.R.B., Pappen, F.G., Faria, N.A.R., Vaz Junior, I.S. (2009). Análise in vitro da eficácia do amitraz sobre populações de Rhipicephalus (Boophilus) microplus (Canestrini, 1887) da região sul do Rio Grande do Sul. Revista Brasileira de Parasitologia Veterinária, 18, 54-57. https://doi.org/10.4322/rbpv.018e1010.

Silva, W.C., Martins, J.R.S., Souza, H.E.M., Heinzen, H., Cesio, M.V., Mato, M., Albrecht, F., Azevedo, J.L., Barros, N.M. (2009). Toxicity of Piper aduncum L. (Piperales: Piperaceae) from the Amazon forest for the cattle tick Rhipicephalus (Boophilus) microplus (Acari: Ixodidae). Veterinary Parasitology, 164, 267-274.

Vélez, J.C.Q., Hidalgo, M., González, J.D.R. (2012). Rickettsiosis, una enfermedad letal emergente y re-emergente en Colombia. Universitas Scientiarum. 17, 82-99. http://dx.doi.org/10.11144/javeriana.SC17-1.rade

Veríssimo, C.J., Katiki, L.M. (2015). Alternativas de controle do carrapato-do-boi na pecuária leiteira. Resistência e Controle do Carrapato-do-boi. Nova Odessa: Instituto de Zootecnia, 113 p.

Yoshinari, N.H., Mantovani, E., Bonoldi, V.L.N., Marangoni, R.G., Gauditano, G. (2010). Doença de lyme-símile brasileira ou síndrome baggio- yoshinari: zoonose exótica e emergente transmitida por carrapatos. Revista da Associação Médica Brasileira, 56, 363-9. https://doi.org/10.1590/S010442302010000300025 